\title{
Zika Vírus e Itinerários Terapêuticos: os impactos da pós-epidemia no Estado do Rio Grande do Norte
}

Zika Virus and the Therapeutic Itineraries: the impact of the post-epidemic in the State of Rio Grande do Norte

\section{Rozeli Maria Porto ${ }^{1}$}

${ }^{1}$ Universidade Federal do Rio Grande do Norte, Natal, RN, Brasil 


\section{Resumo}

O artigo analisa os impactos da pósepidemia do Zika Vírus em mulheres mães de micro residentes no Rio Grande do Norte, a partir de seus itinerários terapêuticos (LANGDON, 1994). Este trabalho pretende fazer uma reflexão sobre o desgaste dessas mulheres na busca por terapias, estímulos e cuidados para as crianças, descrevendo as incertezas e os desconhecimentos dos profissionais de saúde relativos à epidemia e suas relações com a primeira geração de mães de micro. Observa-se como a violência dos direitos fundamentais realça disparidades socioeconômicas, diferenças raciais e de gênero no acesso à saúde, constatando como setores governamentais de assistência são insuficientes para atender às necessidades dessas mulheres, com novas vivências corporais e de cuidado. Os recursos em saúde se apresentaram escassos, por isso, entende-se que na aplicação desses poucos recursos poderia se criar programas mais direcionados à acuidade e com um olhar que envolvesse o conhecimento e a experiência daquelas que lidam com o drama social da deficiência. Foi realizada a observação etnográfica em espaços hospitalares e não hospitalares por meio de entrevistas em profundidade.

Palavras-chave: Zika Vírus. Itinerários Terapêuticos. "Mães de micro".

\section{Abstract}

The article analyzes the social impacts of the Brazilian Zika virus post-epidemic scenario in the lives of women who have given birth to babes with microcephaly, locally so-called "mães de micro" (mothers of micro), in the State of Rio Grande do Norte, Northeast of Brazil. It intents to think about the wear outlived by these women in the seek for therapies, stimulus, and care intended for their kids offered by the government. It describes the uncertainties and unknowing in the health professionals' practices related to the Zika virus outbreak and their relationships with the first generation of "mães de micro". It also observes how violence towards fundamental rights reinforce socioeconomic inequality, and racial and gender differences in the health access processes, showing that the governmental sectors of social aid do not fulfill the necessities of women throughout their new body experience and care. The current institutional resources in health shown to be scarce, and could have more perceptiveness if it was shaped considering the knowledge and experiences of people who deal with the disability social drama. The article is based upon ethnographic observation in hospital and non-hospital spaces, along with in-depth interviews.

Keywords: Zika Virus. Therapeutic Itineraries. "Mães de micro"..

ILHA 


\section{Introdução}

$\mathrm{O}$

transtorno causado nos últimos tempos pela epidemia do zika vírus $^{1}$, trouxe complicações alarmantes ao mundo científico e às Políticas de Estado e de Saúde, estimando-se que um total de 69 países tenham sido afetados por essa epidemia (RASANATHAN et al., 2017a). Além disso, a epidemia surge como evidência circunstanciada para milhares de casos de microcefalia e de outras síndromes neurológicas congênitas ${ }^{2}$, atingindo um grande número de mulheres e de crianças de pelo menos 29 países (DINIZ, 2016a).

No Brasil, no final de 2015, o aumento de casos de microcefalia foi observado especialmente em recém-nascidos da Região Nordeste, suspeitando-se que as mães haviam sido previamente infectadas pelo vírus. Esse fato alimentou dúvidas por parte de cientistas e de profissionais da saúde, como também gerou especulações por parte da população em geral. Concomitantemente aos estudos e às pesquisas acionados em virtude da doença - como os elaborados pelo Ministério da Saúde (MS) (BRASIL, 2015a), muitas reportagens realizadas com especialistas e com outros atores sociais foram divulgadas em importantes jornais de circulação nacional e internacional e nas redes sociais, causando uma série de desconfianças e de desconfortos (COSTA; PORTO, 2017). Diferentes hipóteses, até então não confirmadas, foram levantadas para explicar o aumento dessa enfermidade, a exemplo do larvicida pyriproxipheno, nebulizações químicas, como o fumacê, ou vacinas com data de validade vencida. Essa expansão e o conflito de informações deixaram em dúvida, do mesmo modo, as formas pelas quais eram espalhadas essas doenças (LOWY, 2019). 
Diante da forte convicção de cientistas e de profissionais de saúde brasileiros sobre a epidemia da microcefalia no Nordeste ser resultado da infecção pelo Zika Vírus, essa relação acabou por ser amplamente aceita (CARVALHO, 2017; DINIZ, 2016a; LOWY, 2019) e a atenção mundial voltou-se para esse agente que passou a ser visto como uma grande ameaça de saúde pública (OPAS, 2016).

$\mathrm{Na}$ época do surto, chamou a atenção a maneira de como a responsabilidade por essa epidemia foi efetivamente direcionada, primeiramente retirando a responsabilidade do estado e a redirecionando para os cidadãos "pobres" e "comuns" (SEGATA, 2016). Por conseguinte, o discurso oficial se ancorou em um recorte de gênero, sendo tal responsabilidade repassada para as mulheres, vistas a partir de então como as principais responsáveis pelos cuidados em relação à doença e, do mesmo modo, pela contracepção (SOARES, 2017; PORTO; COSTA, 2017).

O corpo feminino foi abordado como o objeto de análise sobre o qual foram dirigidas as responsabilidades, tanto da prevenção da microcefalia quanto em relação aos cuidados que a mãe deve ter após a contaminação e o nascimento da criança. Nessa perspectiva, não foi raro observar assertivas por parte das autoridades governamentais e da saúde "aconselhando" as mulheres a não engravidarem³ ${ }^{3}$. Discursos que expuseram os corpos das mulheres como decisivamente marcados por um suposto "destino biológico" (ROHDEN, 2001), que comporta evidentes assimetrias de gênero e está presente, sobretudo, na naturalização da ideia de que as mulheres são as únicas responsáveis pela contracepção.

Diante desse drama social, mulheres, em sua maioria de classes populares, enfrentaram diversos obstáculos para poder cuidar de seus filhos. Sem dúvida, foram as mulheres que assumiram efetivamente a responsabilidade pelos cuidados pueris e pelas peregrinações terapêuticas (CARNEIRO; FLEISCHER, 2018; VALIM, 2017). Sem apoio ou informações concretas, essas mulheres se questionavam como iriam cuidar dessas crianças especialmente após o término da licença maternidade, uma vez que não é qualquer cuidador/a que pode assumir a responsabilidade de crianças que necessitam de cuidados 
especiais. São inúmeras as dificuldades, entre elas, a falta de estrutura disponível para o atendimento às crianças, a falta de assistência por parte dos profissionais de saúde, além de dificilmente encontrarem apoio por parte de seus empregadores/as.

Nesse sentido, a "terminologia epidemiológica", como lembra Débora Diniz, fez esquecer que os casos de crianças com microcefalias e outras síndromes foram antecedidos por mulheres adoecidas, pois, ao "falar em casos", ignoraram-se as histórias e os sofrimentos, as angústias e os desamparos. A autora observa que, entre as crianças com sinais indicativos da síndrome congênita, 72\% eram filhas de mulheres da Bahia, da Paraíba, de Pernambuco e do Rio Grande do Norte (DINIZ, 2016b, p. 1), sendo este último o quarto estado brasileiro com mais casos de microcefalia no país. Entre as 532 ocorrências investigadas de 2014 a fevereiro de 2019, 151 foram confirmadas, 125 estavam sob investigação, 247 foram descartadas e outras quatro constavam como inconclusivas ou prováveis (BOLETIM SESAP, 2019a). Os casos notificados estavam distribuídos em 97 dos 167 municípios do Estado, lembrando que a maioria dos nascimentos aconteceu entre os meses de agosto de 2015 a fevereiro de 2016.

Observa-se que o surto acabou por atingir as populações mais vulneráveis desses estados com uma nova e problemática circunstância: afetou diretamente a saúde reprodutiva das mulheres e, em especial, das mulheres de camadas populares e nordestinas (DINIZ, 2016b).

Sobre essa nova e surpreendente condição - que se remete às resistentes assimetrias de gênero e práticas de poder ${ }^{4}$, entrelaçadas a classe e a raça ${ }^{5}$, gostaria de elencar alguns elementos apreendidos sobre uma pesquisa etnográfica em andamento no Rio Grande do Norte.

Na primeira parte, apresento brevemente as motivações para realizar esta pesquisa e a metodologia utilizada. Apresento, ainda, minhas principais interlocutoras Martina, Gisele e Katia ${ }^{6}$, com as quais mantenho contato desde o início da investigação. Na segunda parte, analiso os itinerários terapêuticos dessas mulheres, além de destacar o perfil de outras dez "mães de micro"7 que conheci em campo entre os anos de 2017 e 2019 . Nessa parte, aprofundo as trajetórias de Martina, Gisele e Katia, analisando os aspectos que fazem parte 
desses itinerários, como a busca de atendimento médico, as greves nas instituições hospitalares, as queixas relativas ao transporte público, as dificuldades na aquisição de benefícios, entre outras questões como a alta médica e o acesso ao aborto. Na terceira parte, reflito sobre as incertezas e os desconhecimentos nesses itinerários terapêuticos, tanto por parte dos profissionais de saúde como por parte das mulheres "mães de micro". Reflito ainda sobre o desgaste dessas mulheres na batalha contra o tempo em busca de terapias, estímulos e outros cuidados para essas crianças. Por fim, somam-se ao artigo as considerações finais.

Minha intenção é descrever minimamente alguns impactos da pósepidemia no Rio Grande do Norte a partir dos itinerários terapêuticos e das experiências sociais das mulheres "mães de micro" residentes no estado. Inspiro-me, a saber, na posição de Sônia Maluf (2018, p. 32) que designa por "[...] experiências sociais [...] a dimensão da vivência e produção de saberes e discursos por parte daqueles e daquelas que são justamente o 'público-alvo' das políticas públicas e da atuação dos profissionais e agentes de saúde". Para a compreensão dos itinerários terapêuticos dessas sujeitas, sigo os apontamentos de Jean Langdon (1994), que caracteriza tais itinerários como os percursos de uma pessoa em busca de alívio e cura de suas aflições ${ }^{8}$.

Com tal propósito, penso que etnografar os diálogos, os itinerários e as práticas locais sobre o Zika Vírus e suas consequências às mulheres e a seus filhos dará, de algum modo, visibilidade às suas "epistemologias", às experiências e aos saberes localizados que não são reconhecidos pela biomedicina e, tampouco, como nos lembra Maluf (2018, p. 32), pelas políticas de saúde e do Estado.

\section{Metodologia e Sujeitas da Pesquisa}

A motivação para pesquisar o tema do Zika Vírus e sua possível relação com os casos de microcefalia, entre outras doenças congênitas, surgiu a partir do boom midiático que tomou conta das redes sociais e dos mais variados meios de comunicação a partir de novembro de 2015. Nessa época, eu e outra colega estávamos chegando à Espanha para realizar o pós-doutorado na Universidade de Sevilha e na Universidade Pablo de Olavide, respectivamente. Intrigadas com o tema, passamos 
a analisar notícias em jornais, revistas, artigos científicos e em outras fontes secundárias do tipo bibliográfico, publicadas entre os meses de novembro de 2015 e março de 2016 - ver Porto e Costa (2017).

Quando retornei ao Brasil, resolvi desenvolver um projeto de pesquisa com o objetivo de compreender o impacto dessa epidemia na vida reprodutiva, cotidiana e laboral das mulheres "mães de micro", de seus filhos e de outros familiares pós-surto no Rio Grande do Norte. Embora existissem estudos no campo antropológico brasileiro que já investigassem "as mães de micro" e a propagação das síndromes congênitas (DINIZ, 2016a; FLEISCHER, 2017; SCOTT; QUADROS; RODRIGUES, 2017; CARVALHO, 2017; VALIM, 2017), tal investigação antropológica era inexistente no Rio Grande do Norte, estado bastante afetado pelo surto.

Para tanto, elegi duas instituições de saúde, sendo uma em Natal e outra em Macaíba/RN, como possíveis lócus de investigação. Ambas as instituições foram selecionadas por se tratarem de referências no atendimento às pessoas com deficiência e por terem agilizado rapidamente atendimentos a esses casos específicos provenientes de todo o estado. Desse modo, submeti o projeto ao Comitê de Ética em pesquisa da Universidade Federal do Rio Grande do Norte (UFRN) no início de 2017, selecionando essas duas instituições para pesquisa projeto posteriormente aprovado.

Ao mesmo tempo, troquei ideias com colegas da área da saúde, da antropologia, da psicologia e das ciências sociais que trabalhavam na UFRN e também em outras universidades. Conversei com pessoas lotadas nas secretarias dos departamentos na UFRN, com bolsistas e alunos e também com as Auxiliares de Serviços Gerais (ASGs), especulando se alguém teria algum conhecido/a, parente ou vizinho/a que naquele momento estivesse vivenciando tal processo. Afinal, o contexto televisivo, jornalístico e as redes sociais noticiaram incansavelmente o assunto, embora ele tenha se diluído frente aos acontecimentos históricos e políticos, a exemplo do impeachment de Dilma Rousseff (COSTA; PORTO, 2017). De qualquer modo, todos estavam bastante intrigados sobre como esse vírus havia se propagado com tamanha força pelo Nordeste do país. E, consequentemente, questionávamos qual seria a resposta do Estado a essas famílias. 
Mas foi somente a partir do WhatsApp (software para smartphones utilizado para troca de mensagens de texto instantaneamente por meio de uma conexão à internet) que consegui realizar os primeiros contatos para a pesquisa. Simultaneamente a essas conversas, trocas e esperas, especialmente no que se refere à avaliação do Comitê de Ética do projeto, enviei uma mensagem de texto pelo WhatsApp para pessoas que fazem parte da minha lista de contatos, as quais, sob meu ponto de vista, poderiam render-me algum retorno. Sem demora, uma colega de profissão passou-me o contato de Martina (nome fictício), que viria a ser uma de minhas principais interlocutoras.

Fui incluída no grupo de WhatsApp criado por Martina e por outras mulheres, chamado "Mães Escolhidas por Deus" (MED), mantendo contato virtual com 50 mulheres que faziam parte desse grupo. A escolha desse nome, segundo minhas interlocutoras, justifica-se pela religiosidade dessas mães, a maioria católica, as quais acreditam ser pessoas especiais, uma vez que "Deus não escolheria qualquer mulher para cuidar de uma criança com deficiência”. Apenas em dezembro de 2018 elas conseguiriam fundar sua associação em uma escola particular na zona sul de Natal/RN.

Entre as 50 mulheres, três aceitaram me receber em suas casas para serem entrevistadas, após conversarmos pelo WhatsApp ou por telefone. Conheci outras cinco mulheres pessoalmente após obter autorização do comitê de ética, quando comecei a pesquisar os centros de saúde selecionados para investigação em Natal/RN e em Macaíba/ RN. Ainda tiveram outras cinco que conheci em momentos festivos em um centro comunitário e na sede da associação. Conversei com os últimos dois grupos de mulheres mais do que uma vez, não obstante, de maneira informal. Nunca encontrei todas elas juntas, à exceção de uma festa junina promovida pelo grupo em 2018 em que a maioria estava presente.

Segundo Gisele, uma das mães fundadoras da associação, essas mulheres têm muitas dificuldades em sair de casa por causa da condição dos filhos. As saídas, para além das consultas médicas, são realizadas somente se existir algum tipo de benefício que faça parte de seus interesses: distribuição de leite em pó, fraldas, lenços descartáveis, 
entre outros utensílios. Ou quando existe a presença de autoridades que consideram importantes e possam lhes trazer algum auxílio - a exemplo de políticos locais. Esse fato gerou muitas críticas por parte de Gisele e de Martina. Elas argumentam que, embora compreendam a situação, deveria haver maior empenho e união de todas para o fortalecimento da associação?.

De qualquer modo, esses contatos que aconteceram entre os meses de agosto 2017 a abril de 2019 marcaram meu campo de pesquisa de maneira bastante emocional. Afinal, nessas questões intersubjetivas, foi quase impossível não me afetar com suas histórias de vida, sofrimento e superação (FAVRET-SAADA, 1990). Conheci pessoalmente 13 delas, seus filhos e filhas, sendo que no decorrer do trabalho de campo acompanhei mais de perto três dessas mulheres: Martina, Gisele e Katia (nomes fictícios usados para preservar a identidade das sujeitas desta pesquisa, conforme sugere Fonseca (2003)).

Martina está hoje com 44 anos, além de ser a mais velha em relação as outras mulheres, ela também é a única representante com melhores condições financeiras, formação superior, sendo Martina e seu marido concursados em instituições públicas. Católica não praticante, possui dois filhos: um menino com 7 e outro com 4 anos, sendo o último portador de microcefalia por ZKV e outras síndromes congênitas infecção detectada por meio de exames laboratoriais - assim como os filhos de Gisele e Kátia. Mora em um bairro de classe média em Natal, considera-se branca, tendo nascido nesta mesma cidade. Observou que ela e o marido, segundo casamento, não desejam mais ter filhos.

Gisele, 24 anos, é casada, católica e tem dois filhos. Um menino com 8 anos e a menina portadora de microcefalia por ZKV com 4 anos. Possui Ensino Médio incompleto, residente na zona norte de Natal/RN, num local de pouca infraestrutura no que diz respeito a saneamento básico, mora em casa alugada e é natural da cidade de Tangará/RN. O marido estava desempregado na época e não tinha uma profissão definida. Deseja ter outro filho em um futuro distante. E, quando perguntada sobre sua cor/raça, disse que se considerava parda.

Katia, 28 anos, casada (segundo casamento), católica, dois filhos. Um menino com 12 e outro com 4 anos. Ambos portadores de 
deficiência, sendo o último detectado por conta do ZKV. Possui segundo grau completo e faz curso técnico de enfermagem. Como o marido de Gisele, o dela também estava desempregado. Natural da cidade de Natal, se considera branca e mora em uma casa emprestada por sua avó, na zona sul da cidade. Não deseja mais ter filhos.

Martina, Gisele e Kátia são três mulheres com histórias de vida diferentes, de classes sociais e escolaridades diversas, mas que, por causa da epidemia do Zika Vírus, acabaram por partilhar dores, sofrimentos e itinerários terapêuticos em alguns momentos muito semelhantes.

Durante a pesquisa, tive a oportunidade de acompanhá-las em festas, reuniões, entre outros encontros, tanto em suas casas como nos centros de saúde e na escola em que possuem a sede das "Mães Escolhidas por Deus". Mantivemos muitas conversas por e-mail, por telefonemas e WhatsApp, além de conseguir realizar com elas entrevistas em profundidade. Lembro que profissionais de saúde também foram acompanhados e contatados, algumas conversas e entrevistas foram realizadas, mas para este artigo elenquei apenas a entrevista de uma enfermeira especialista em saúde pública. Por isso, adiante, penso ser importante retratar brevemente o perfil das 13 mulheres que mantive contato, incluindo falas intercaladas de minhas principais interlocutoras, as quais acompanhei mais de perto no decorrer da investigação.

\section{Dores, Sofrimentos e Itinerários Terapêuticos}

De forma geral, o perfil das 13 mulheres contatadas no Rio Grande do Norte - e aqui estão incluídas Martina, Gisele e Katia - não difere do perfil das mulheres que encontramos na literatura sobre o tema (DINIZ, 2016b; VALIM, 2017; FLEISCHER, 2017; SCOTT; QUADROS; RODRIGUES, 2017; WILLIAMSON, 2018, etc.). Observa-se que 12 entre as 13 mulheres pertencem a camadas populares da região. Dez possuem Ensino Fundamental (completo/incompleto), duas delas, Ensino Médio e outra ainda Ensino Superior Completo.

No que diz respeito ao quesito raça/cor, (conforme definição do IBGE), oito se consideram pardas, três negras e as outras duas se 
consideram brancas. Todas são nordestinas. Oito dos maridos entre as 13 mulheres com as quais conversei na época estavam desempregados. Duas moram em áreas saneadas de Natal. Onze na zona norte de Natal/RN e Macaíba/RN, áreas pouco ou nada saneadas. Seus filhos e filhas possuem diferentes níveis e graus de síndromes congênitas, os quais apresentam comprometimento nas funções motoras, visuais, auditivas, cognitivas e alteração de comportamento. São jovens, tendo menos de 28 anos (apenas Martina está com 44 anos). Embora nem sempre atendidas como deveriam, no que diz respeito aos seus direitos fundamentais, todas foram inicialmente acompanhadas por equipes multiprofissionais em diferentes locais, tanto em Natal/RN como em Macaíba/RN. A maior queixa dessas sujeitas são as constantes greves nos serviços públicos. Reclamação que pode ser traduzida nas falas de Gisele e de Katia:

Depois de dois meses fui para o CRI [Centro de Reabilitação Infantil de Natal/RN]. Ela [a filha] come direito, não precisou de fono. Lá tinha ginet [...] [geneticista], neuro, mas agora com essas greves piorou... La é só duas vezes, se quiser fazer mais tem que procurar outro lugar [...] Mas sempre tá em greve. Sempre em greve e daí piora a menina... (Gisele).

Levo o meu filho em dois lugares diferentes... Duas vezes por semana no CRI para fazer fisio. E duas vezes na UNI RN. O CRI é vizinho do parque das dunas e está deteriorando [...] Vive em greve. Agora está funcionando. Mas não demora entra em greve. Deveria investir lá em mais profissionais [...] Greves, o governo não paga, quando não é médico, é terapeuta, ou pessoal da limpeza $[\ldots]$ (Katia).

As greves constantes acabam por comprometer o atendimento de seus filhos e, consequentemente, retarda a efetivação dos procedimentos e os estímulos às crianças, uma vez que essas mães têm atendimento apenas duas vezes por semana ${ }^{10}$, à exceção de Katia que mora praticamente ao lado do Centro Universitário do Rio Grande do Norte (UNI/RN), o que facilita o deslocamento. Mas, via de regra, a maioria das mães mora distante dos centros de atendimento. Quando não em outro município onde não há a mínima estrutura para qualquer tratamento. 
Nenhuma delas comentou sobre seus filhos terem recebido alta médica, seja compulsória ou não (SCOTT; LIRA; MATOS, 2018; CARNEIRO; FLEISCHER, 2018), fato que discutiremos adiante, mas todas têm medo de serem desligadas dos programas se houver a necessidade de faltar mais de três vezes por alguma razão.

Outra queixa frequente se refere ao transporte, pois o carro da prefeitura quebra vez ou outra, e/ou não existe disponibilidade para transportá-las justamente no dia marcado para atendimento. Alguns motoristas de ônibus também não prestam auxílio ao perceberem que essas mães estão com carrinhos de bebês ou em cadeiras de rodas. Pior que isso, segundo minhas interlocutoras, é o preconceito desses motoristas que não param o ônibus pelo simples fato de perceberem as anomalias nas crianças. Argumentam também que necessitam faltar ao Centro de Saúde pelo agravamento no estado de saúde de seus filhos em diferentes momentos.

Em certos casos, essas mães deixam de comparecer às consultas pela simples falta de esclarecimentos. Quando estava na maternidade correndo atrás de assinaturas para o Comitê de Ética em Pesquisa, soube, por intermédio de uma fisioterapeuta, que uma das mães deixou de levar a filha para o programa por medo de perder o Benefício de Prestação Continuada (BPC) ${ }^{11}$, caso a criança apresentasse melhoras. Tal benefício, em muitos casos, torna-se a única fonte de renda para a compra de medicamentos e para a alimentação dessas crianças, quando não garante o sustento de toda a família. Sobre o BPC, apenas Katia encontrou obstáculos em acessar o benefício por ter dois filhos na mesma situação de deficiência. O Estado só admitiu o pagamento para o mais velho, tendo minha interlocutora recorrido à justiça. Aliás, segundo Katia, recorrer à defensoria é o caminho para se alcançar qualquer direito no que diz respeito às pessoas com deficiência.

[...] Ainda não tinha aprendido o caminho da defensoria. Então, entrei na justiça porque eu preciso da ajuda do governo. Vou na defensoria para conseguir ressonâncias, cadeira de rodas, esse é o termo de compromisso para comprar a sonda [mostra muitos papeis], e esse aqui foi o do benefício. Entrei na justiça porque o meu mais velho já recebe. Direito apenas para o primeiro. Imagina uma lata de leite para esse aqui custa 200 reais. No posto não 
tem. Não encontra. Tudo tem que comprar. Cadeira de roda, de banho, beneficio, tudo pela justiça... (Katia)

Katia tem em mãos uma pasta cheia de papéis com todos os documentos necessários para realizar suas reivindicações em nome de seus filhos. E, observa que, mesmo assim, encontra uma série de dificuldades. Além de a defensoria ficar distante de sua casa, o atendimento por vezes leva até duas horas para ser efetivado, sendo Katia a única cuidadora de seus dois filhos ambos portadores de deficiências.

Nesse sentido, observa-se, a partir dos discursos dessas mulheres, que as cuidadoras são majoritariamente as mães dessas crianças. Filhas mais velhas, avós e sogras auxiliam nos cuidados. Vi apenas um pai dividindo efetivamente as tarefas com a esposa em dois encontros festivos em que estivemos juntos. Scott, Lira e Matos (2018, p. 678) observam que os companheiros, quando participam dos cuidados, não são cobrados da mesma maneira que as mulheres:

Os elogios a homens que "ajudam" são enaltecedores das suas maneiras de se dedicarem às novas demandas. Isto não acontece da mesma maneira com mães, irmãs, amigas, e, inclusive, outras mães em condições semelhantes, de quem se espera mesmo a ajuda e solidariedade. Nem este conjunto de apoios elimina uma sensação de isolamento vivido por muitas mães com os seus filhos. A demanda para segurar os muitos filhos - que dormem mal, são irritadiços, não se sustentam sós, têm problemas de deglutição, experimentam muitas convulsões e, pela sua vulnerabilidade, são susceptíveis a outras doenças, precisam ser levados para consultas, hospitais, clínicas, unidades de terapia - é suficiente para afastar muitos potenciais cocuidadores e fazer com que os que ajudam sejam muito bem apreciado(a)s.

Em sua maioria, os companheiros, mesmo desempregados, não assumem paritariamente tarefas domésticas, burocráticas ou de lazer. Algo que a literatura de gênero e a feminista evidencia histórica e culturalmente, demonstrando como os cuidados maternos foram relegados às mulheres, sendo que, por vezes, elas mesmas não cedem esse espaço por uma série de razões ligadas à compreensão de que a 
tarefa doméstica e os cuidados aos filhos recai sobre as mães (ROHDEN, 2001; SCAVONE, 2001; FUNCK, 2014). Observa-se, ainda, que nove, entre as 13 mulheres com as quais tive contato, disseram não ter planejado a gravidez. E a descoberta de uma ou mais síndromes se deu no final de suas gestações (cinco), ou logo em seguida ao nascimento da criança (seis). Não tenho informações sobre as outras duas mulheres.

Adiante, nenhuma delas teria ouvido falar que algum médico teria sugerido a interrupção da gravidez para aquelas que souberam da malformação antes do parto, conforme observado por Carneiro e Fleischer (2018) em sua pesquisa com mulheres em Recife. Contudo, no último encontro com o esse grupo, soube, por meio de uma assistente social, que duas delas comentaram que seus médicos teriam sugerido o aborto. Fato que revela outra perspectiva por parte desses profissionais de saúde (médicos/as), no que diz respeito a um assunto bastante espinhoso entre a categoria - como tenho observado nos últimos anos, especialmente em Natal/RN e arredores (PORTO; SOUSA, 2017; COSTA; PORTO, 2018).

Aliás, deve-se ter em mente que falar sobre aborto com mulheres que estão numa corrida desenfreada pela sobrevivência e bem-estar de seus filhos foi uma tarefa bastante difícil e melindrosa. Em meio aos questionamentos sobre seus itinerários reprodutivos, tentei abordar o tema "aborto" procurando não ultrapassar os limites entre pesquisadora/ pesquisadas, pensando cuidadosamente no momento e nas palavras certas que seriam por mim instrumentalizadas para não as ofender. Construí junto a essas mães uma relação de respeito e de admiração, que não poderia se esvair por conta de questões mal formuladas ou insensíveis. Qualquer deslize em torno do tema poderia fechar as portas desse campo de pesquisa, precioso demais não apenas pelos meus anseios epistemológicos, mas sobretudo pela reciprocidade e pelo afeto que nele foram construídos. Tanto que somente no segundo ou terceiro contato abordei o assunto com minhas entrevistadas, mas sem muito sucesso. Suas preocupações giravam em torno do que consideravam ser, naquele momento, as questões mais urgentes e concretas: a garantia do direito à saúde e do bem-estar de seus filhos. 
Além disso, muitas queixas realizadas por elas diziam respeito ao quanto seus direitos reprodutivos foram violados na hora do parto, seja na busca por um leito nas maternidades em Natal ou Macaíba, seja pelo mal atendimento, ou ainda pela surpresa de como os profissionais de saúde manipularam seus corpos grávidos, revelada por meio da falta ou do excesso de medicamentos, pelo desrespeito, pelo preconceito ou ainda pela simples falta de "cuidado" - como por vezes me disseram algumas interlocutoras. Nessa perspectiva, somente Martina emitiu opinião sobre o tema. Na realidade, Martina é uma exceção entre minhas entrevistadas, no que diz respeito à classe, à raça e à escolaridade como já observado. Ela mesma não se conforma de ter sido infectada pelo vírus por trabalhar e morar em áreas saneadas de Natal. Tampouco viajou há época para outros lugares correndo o risco de infecção. Diz que ter zika foi um processo paradoxal, uma vez que trabalha com temas ligados a projetos de saneamento básico.

Martina começou a falar espontaneamente sobre o assunto, primeiramente porque em seu caso havia a desconfiança do filho ser portador da síndrome de Edwards. Observa que ela e o marido chegaram a trocar algumas ideias sobre a hipótese do aborto, pois poderiam ter recorrido à justiça em se tratando de um episódio de malformação fetal sem perspectivas de sobrevivência. Mas essa ideia foi bastante passageira, pois, além de não terem certeza do diagnóstico, ambos desejavam muito ter esse filho. Por outro lado, desabafa em torno do assunto:

Esse mesmo estado que proíbe o aborto, relega ao esquecimento e total abandono o cidadão deficiente. Isso é paradoxal. Em países que tem mais dignidade, o aborto não é proibido. Mas aqui, tem esse discurso porque é crime, por outro lado se maltrata esse feto e as mulheres de outras formas. Eu acompanho muitas delas e vejo que tem diversos problemas. Não conseguem trabalhar, não porque não queiram, mas porque não podem. E sem trabalhar, sem vida produtiva, é tudo muito aprisionante [...] A gente se anula por completo. Fica doente [...] Tenho apoio psicológico, se não teria me anulado totalmente. Eu tinha essa tendência de deixar o trabalho... eu me sentia culpada! Se ele morresse, a culpa era minha. Qualquer coisa eu era a culpada. As mulheres são maltratadas e ainda são ameaçadas de perderem a vaga nos centros de reabilitação, não importa se perderam o ônibus, 
ou o carro da prefeitura está quebrado. Elas têm outros filhos, tem que pegar ônibus, saem na chuva, é um universo onde nos sentimos muitos sós. O Estado é ausente. Ele é responsável pelo tipo de educação que tem e que dá. Quando vai olhar o mosquito de forma séria? Nós também temos culpa por muitas coisas... a sociedade quando vê a criança com micro chora, sente porque a criança está em situação de rua, se sensibiliza com esta imagem, mas não toma atitude para mudanças. Essas crianças vieram para chacoalhar a sociedade, mas ainda não conseguiram... convenhamos que diante de todas estas circunstâncias proibir (o aborto) certamente é uma hipocrisia [...] Mas, este, lógico, deveria ser visto de forma séria e não como um expurgo para a sociedade.

Para Martina, existe em nosso país uma situação paradoxal em torno da saúde reprodutiva das mulheres e a deficiência, sobretudo, após o advento do Zika Vírus. Observa que a sociedade condena o aborto como um crime ignominioso e, ao mesmo tempo, não toma atitudes para possíveis mudanças em relação à epidemia, ao acesso à saúde e suas instituições, relegando o cidadão deficiente "ao esquecimento e total abandono". Chama atenção para as contradições impostas por uma sociedade que acaba por não valorizar a dignidade dessas sujeitas, mulheres/mães, não lhes permitindo escolhas, diante de seus dramas pessoais e de suas experiências sociais.

Com efeito, a partir do momento em que algumas mulheres recorreram ao aborto preventivo, imediatamente após o anúncio do MS durante o surto, tal fato refletiu firmemente nessas desigualdades sociais/ raciais. Observa-se que, a partir daí, existe um aumento nos abortos seguros/clandestinos, ainda que seletivos por status socioeconômico. Tanto que a epidemia resultou em uma geração de bebês com síndrome do zika congênita (CZS) que refletem e exacerbam tais desigualdades, inclusive regionais. Minhas interlocutoras, à exceção de Martina, fazem parte das camadas mais pobres pertencentes à zona norte de Natal e Macaíba. Regiões carentes de saneamento básico, coleta de lixo, assistência à saúde e, sem dúvidas, de planejamento familiar.

São mulheres que se encontram numa via-crúcis para conseguirem consultas, atendimentos, exames, fisioterapias e, consequentemente, ficam expostas a tormentos psicológicos (GASTÓN, 2018), ao desamparo 
e às violências institucionais na saúde (AZEREDO; SCHRAIBER, 2017). Não foi raro, por exemplo, ouvir relatos de maus-tratos durante o prénatal ou mesmo durante os partos ${ }^{12}$. Maus-tratos que acabam por ter continuidade na busca de melhores condições de vida para seus filhos, os quais necessitam de cuidados especiais e despendem gastos quase impossíveis de serem bancados sem o auxílio do Estado.

Nesse contexto de emergência e de relações fortemente hierarquizadas, essas mulheres tiveram que lidar com os imbróglios de uma síndrome pouco conhecida por cientistas e outros profissionais de saúde, o que gerou, especialmente no início do surto, uma série de desconfortos e de constrangimentos entre profissionais e usuárias dos serviços de saúde locais.

\section{4 “Mas o Que é Zika?" "Micro?" "Estímulo?" - Aprendizados e a Questão do "Tempo"}

A maioria dos nascimentos de microcéfalos no Rio Grande do Norte aconteceu entre agosto de 2015 e fevereiro de 2016 (POSENATO GARCIA, 2018). Até então não havia entre os profissionais de saúde um consenso sobre o que estava acontecendo, tampouco havia preparo das equipes hospitalares para atender a tantos casos. Fato que, do mesmo modo, ocorreu em vários outros Estados da Federação (LIRA; SCOTT; MEIRA, 2017).

$\mathrm{Na}$ instituição de saúde pesquisada em Natal/RN, não foi raro observar o nascimento de um grande número de crianças com microcefalia e outras síndromes congênitas. Em um mesmo dia, por exemplo, sete dos 24 leitos existentes na instituição estavam ocupados por crianças portadoras com tal enfermidade. Conforme nos informa Juliana, enfermeira e minha interlocutora na maternidade, os esforços de médicos/as e outros/as especialistas para encontrarem soluções urgentes acabou por gerar desconforto às mulheres pela abordagem pouco sutil e reflexiva realizada por estudantes e profissionais de saúde ligados às áreas de enfermagem, medicina, fisioterapia, fonoaudiologia, entre outras. Perguntas como "A senhora teve zika? Fez pré-natal? E lá no pré-natal não viram que a senhora teve zika?", ou ainda, "esse bebê precisa de estímulo" ... "Olha, seu bebê nasceu com microcefalia"... Entre outras 
advertências, causaram estranhamento por parte das mulheres que não compreendiam o que estava acontecendo: "Mas o que é zika"?... "O que é isso" (microcefalia)? "O que é estímulo"?

Juliana explica que esses profissionais tinham um tipo de compreensão pré-concebida sobre a microcefalia ser o resultado da infecção causada pelo Zika Vírus, relação recentemente apresentada pelos cientistas há época do surto. E, além de uma abordagem linguística e científica pouco apropriada às mulheres, o desrespeito aos seus direitos fundamentais transparece nessa relação entre médicos $x$ pacientes envolvendo, sobremaneira, “[...] o exercício de micropoderes em contextos de desigualdades sociais" (GARNELO; LANGDON, 2005, p. 142).

Todavia, não se deve desmerecer a agência instituída por essas mulheres em relação às abordagens dos profissionais de saúde. Juliana explica que algumas já cansadas em responder às perguntas, que para elas eram irrefletidas e sem nexo, logo iam dizendo: "[...] ah, eu já digo que tive (zika) que é pra me ver livre"... Porque os médicos e outros chegam direto perguntando isso... E então elas respondem: "tive, tive zika sim". E talvez nem tivessem tido".

De qualquer modo, a enfermeira chama atenção que o pós-parto é um momento em que as mulheres normalmente se sentem muito cobradas e acuadas em relação à amamentação, à higiene ou à saúde do bebê: "[...] imagine-se diante de tal situação, em que todos estavam sem entender o que estava acontecendo com essas crianças ... E, em meio a isso, todas as cobranças normais feitas às mulheres depois que dão à luz". Juliana explica que, para a mulher que acabou de parir, a construção da maternidade é um processo bastante complicado. Observa que, além de todas as transformações corporais e psicológicas, a atenção pós-nascimento é normalmente direcionada ao bebê, relegando a mulher ao segundo plano:

Para mulher é difícil porque acabou de parir, difícil processo de maternidade, todos vão visitar, querem saber do bebê, ele tem que estar arrumadinho, etc. Se é menino já querem saber o nome, se tem a ver com o pai, se é Junior, ninguém olha pra mãe e diz 'você tá linda' e tal. Ninguém olha para a mulher somente para o bebê, e quando olha é para cobrar: 'está amamentando? E aí o bebê tá mamando?' e a gente vê que a mulher já fica um pouco aflita 
com tais cobranças, e tem toda essa... Tem que mamar... Então quando chegou o Zika Vírus, quando chegou a microcefalia, esse universo é diferente, o bebê é diferente, aparecem às diferenças: ‘Não foi parto normal? Foi cesárea? Não foi? E aí [...] Entendeu? Foi menino, tem quantos em casa, tem 2, agora depois desse vai ter outra ainda né?' (Juliana).

Existem aí normativas que acabam por diferenciar as "mães de micro" das outras mães: quando são "simplesmente mães", elas acabam sendo relegadas a segundo plano, mas, quando elas são "mães de micro", são trazidas para o primeiro plano, todavia, se tornando as suspeitas e as responsáveis pelo acontecimento. A enfermeira observa que as consequências de uma criança portadora de uma síndrome aumenta, via de regra, a exigência que se impõe sobre as mulheres no momento do pós-parto. Cobranças que acabaram sendo ainda mais evidenciadas pelo aumento de crianças com microcefalia e outras síndromes congênitas há época da epidemia.

Relatos semelhantes são trazidos por Gisele e por Martina. Gisele, por exemplo, observa ter realizado o pré-natal completo, não havendo desconfiança sobre qualquer tipo de malformação. Realizou, inclusive, ultrassom um dia antes do parto (que não se deu sem angústias ao percorrer uma via-crúcis por maternidades da capital e arredor) que, segundo ela, nada fora detectado. Contudo, imediatamente após o nascimento da filha, foi observado pela médica pediatra uma suspeita de microcefalia, diagnóstico comprovado tempos depois por exames laboratoriais: "Então eu não tinha desconfiança de nada"... aí, quando a médica disse ainda na mesa do parto "a menina tem micro!"... "já comecei a ficar nervosa... o que é que ela tem? O que é micro?".

Gisele disse ter tomado conhecimento do surto pela televisão alguns dias depois de dar à luz a sua filha mais nova. Ressalta o quanto sofreu pelo descomprometimento dos profissionais de saúde quando, em meio ao desespero, buscava alternativas para o tratamento da criança. Entre as notícias midiáticas e o contato com outras mães, teve certeza de que ter adoecido pelo zika durante a gravidez acabou por afetar gravemente sua filha na gestação:

Não tinha nenhum caso, estava sem saber [...] O médico mandou

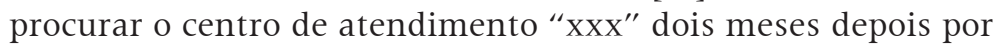


causa da cesárea, mas fui em seguida. Daí, conversei com o médico de lá e ele disse 'ela tem microcefalia e pronto. Não tem o que fazer'. No instituto "xxx", eu perguntei "e agora doutor?", eu não sabia o que fazer e o médico não encaminhou nada. Depois encaminhou pra ela fazer uma ultra e mais nada... Daí, eu vi no jornal que crianças estavam nascendo assim. Foi quando tive certeza. Quando passou no jornal e pronto, mancha vermelha e tal [...]. Na TV deu isso. A única coisa que tive foi isso. Depois fui conhecendo outras mães que tiveram o mesmo que eu tive na gravidez [...] (Gisele).

Importante lembrar que, no início da epidemia, os mais diversos especialistas na área da saúde não tinham certeza do que estava acontecendo e, consequentemente, o suporte no atendimento às mães da primeira geração de microcéfalos por zika foi ineficiente. Esse desconhecimento, porém, não justifica a indiferença ou o preconceito existente nas relações entre médicos/as e pacientes naquilo que algumas autoras identificam como violência institucional em saúde (AZEREDO; SCHRAIBER, 2017) ou como racismo institucional (LÓPEZ, 2012).

De qualquer modo, fica evidente a existência de uma dinâmica conflituosa entre profissionais e pacientes que se intersecciona, de fato, nessas questões de gênero, classe e racismo - quando não geracionais. Como nos informa Nascimento e Melo (2014, p. 274), “[...] se alguns profissionais destes cenários compreendem a insatisfação dos usuários frente a forma como os serviços públicos de saúde são disponibilizados, há outros que assumem um posicionamento oposto". Ou seja, o saber biomédico que contamina boa parte dos profissionais de saúde desconsidera que as mulheres sejam "sujeitas de direitos" (LÓPEZ, 2012). Nesses espaços hospitalares, a maioria delas é composta de mulheres pobres e negras, sendo que muitas não escapam dos maustratos cometidos por uma cultura construída a partir de práticas e de significações ancoradas em paradigmas racistas, sexistas, sobre condições sociais assimétricas e/ou menos abastadas (MACHADO, 2006; GARNELO; LANGDON, 2005).

Por outro lado, esse desconhecimento por parte dos especialistas poderia se encaixar no que Scott, Lira e Matos (2018) e Fleischer e Carneiro (2018) abordam sobre a alta médica. Embora nenhuma de minhas interlocutoras tenha comentado o tema, (como visto 
anteriormente), tais ações, a exemplo das relatadas por Gisele, podem invisibilizar essa falta de interesse do Estado por um ser considerado “improdutivo". Como destacam Scott, Lira e Matos (2018, p. 679):

As ações que mais corroem as relações entre as mães e o Estado se repete nas ações que sugerem que o setor onde o filho está se tratando desistiu de apostar em sua melhora, sendo por desleixo na organização, sendo por ações como "altas" flagrantemente falsas, que são interpretadas sistematicamente como "dispensas" por inviabilidade produtiva. É como se sempre fossem os pacientes de salas de emergência com poucos médicos e muitos pacientes, nas quais os médicos e profissionais de saúde abertamente assumem que decidiram atender os que tinham mais "chance". É uma passagem de comunicação de "estamos fazendo tudo para ajudar a você e seu filho" para uma comunicação que "já desistimos e terá que arcar com todo o peso do cuidado do seu filho daqui em diante".

Contudo, deve-se ter em mente que muitos/as desses/as profissionais prestaram atenção no direcionamento ao "cuidado" para com essas mães e seus filhos, como pude presenciar em minha etnografia no Centro de Saúde em Macaíba, e também na narrativa por parte de outras interlocutoras. A própria Gisele observa que durante o parto, embora tenha sido bastante maltratada pelo médico obstetra, profissionais que participaram da equipe lhe deram "bastante carinho", dizendo a ela que "não se preocupasse naquele momento com o problema da filha", pois tudo "ficaria bem". E, assim, a partir desse total desconhecimento, inicia seu itinerário terapêutico que não se diferencia das trajetórias das outras mães que estão passando pelo mesmo processo.

Martina teve seu percurso um pouco diferente do percurso de Gisele. Ela descobriu na $24^{\circ}$ semana que seu filho não tinha dois dedos em uma das mãos, fato que a deixou bastante aflita. Contudo, o restante do exame demonstrava estar tudo normal. Porém, com 32 semanas, uma ultrassonografia de urgência revelou enfermidades de várias desordens cerebrais, cerebelares, pé torto congênito, novamente sem os dedos. Com o nascimento do filho, diversos exames foram realizados sempre com os piores diagnósticos. Até ser descoberto por um geneticista que a criança tinha provavelmente sofrido infecção 
pelo zika ou chikungunya. Informação até então incerta "que circulava somente entre a classe médica para não causar pânico na população", segundo Martina. Sem muito mais o que fazer naquele momento de pânico e de desconhecimento, o médico recomendou vários cuidados e, entre eles, a estimulação: "Cuidem dele - a criança estava na UTI - "cuidem dele, estimulem, estimulem"... Discurso médico que não passa despercebido por Martina:

[...] é toda essa coisa da estimulação precoce que se popularizou, e na época a gente nem sabia do que se tratava: estimular, estimulem, estimulem [...] De repente, todas as mães tiveram que sair correndo atrás disso, pois sem a estimulação seu filho ficaria para traz, sem desenvolvimento, sem falar, andar, ouvir, respirar, comer" [...] Mas a que preço? (Martina).

A estimulação precoce pode ser definida como "[...] um programa de acompanhamento e intervenção clínico-terapêutica multiprofissional com bebês de alto risco e com crianças pequenas acometidas por patologias orgânicas - entre as quais, a microcefalia [...]" (BRASIL, 2015b), sendo que tal estimulação deve ser realizada logo após o diagnóstico do bebê, com especial atenção aos três primeiros anos de vida.

Com as especulações em torno da estimulação precoce e de todos os cuidados em relação a essas crianças, Martina compreendeu, a duras penas, que "o tempo" seria fundamental para o desenvolvimento de seu filho, portador de microcefalia e de uma série de outras síndromes que o prendem até hoje a um rizoma de aparelhos. Há época do surto, ela se perguntava como e de que maneira essas outras mães iriam conseguir "burlar o tempo" que restava para "estimular" precocemente os seus filhos. Consciente do péssimo sistema de saúde pública e do caos que, como via de regra, se instaura nos hospitais e em outros centros de atendimento em Natal/RN e arredores, poucas esperanças sobrariam para a maioria dessas mulheres. Previsão que se confirma especialmente por conta das greves em serviços públicos, mas que também se reflete no arrefecimento de projetos realizados por instituições de ensino particulares, talvez, imagina-se, pela falta de financiamento das agências de fomento. 
Adiante, a medida do "tempo" para Katia também se transforma com o nascimento do segundo filho, portador de várias anomalias congênitas, segundo ela, devido à infecção pelo Zika Vírus. Disse que ainda grávida foi diagnosticada com dengue, "pois a gente não escutava nada sobre falarem em surto de zika". Aos seis meses, descobriu a microcefalia entre outras várias deficiências, lembrando que o primeiro filho já possui problemas cognitivos e dificuldade de aprendizagem:

Fiquei em choque [...] Eu tenho um filho deficiente e daí entrei em depressão [...] Mesmo assim, respirei fundo e fui pesquisar tudo sobre microcefalia. Foi muito difícil encontrar famílias assim. Eu queria saber como e onde conseguiria atendimento. A quem eu deveria recorrer. E desde que ele nasceu nunca mais tive tempo para nada: são vários exames, consultas com diferentes especialistas, corro o tempo todo atrás de fisioterapia porque precisa de estímulo, ele precisa de medicamentos [...] Faço tudo isso abaixo de chuva, abaixo de sol, em lugares que ficam distantes uns dos outros. Uma luta [...].

Sua vida, a partir de então, imprime um ritmo frenético, cansativo e desesperador. A questão do tempo para Katia, assim como para outras mães, tornou-se decisivo no desenvolvimento da criança. Porém, esse é, muitas vezes, "um tempo que se ganha e que se perde", pois, todo o progresso do seu bebê por meio dos estímulos proferidos em várias sessões de fisioterapia se perderam com as convulsões:

Ele recebeu alta com 17 dias. Começou a fazer fisioterapia com 22 dias [...] Melhorou muito: essa perna era todo para trás, os pés encostados assim (mostra como eram), fisio de segunda a sexta. Melhorou muito só com a terapia e esses estímulos [...] Aí, veio desenvolvendo legal, bem, mas com 4 meses começaram as convulsões. Ficou internado durante 1 mês. Foi diagnosticado com Síndrome de West tendo que usar um medicamento caríssimo [...] Começou a regredir por causa das convulsões. Estava sentando sozinho, perdeu. Controle de tronco, perdeu. Começou a atrapalhar a parte da deglutição, pneumonia, broncoespasmos, uma atrás da outra, outra internação, mais 3 meses internado, 45 dias de UTI, saiu de lá com pneumonia bacteriana, infecção generalizada [...] Que barra para essa criança [...] Pressão lá embaixo [...] Respondeu bem ao antibiótico com o passar dos dias. Da UTI fomos para casa. Passou mal novamente, voltei pra médica, e eu me comprometi com a fisio respiratória, tive que gastar o 
que não tinha, fisio particular [...] Melhorou. E essa questão de andar, falar é o que menos importa [...] (Katia).

A maioria dessas mulheres, após acompanhar nos últimos anos o tratamento de seus filhos/as, já consegue discernir terminologias médicas e especializadas que antes eram completamente desconhecidas em seu dia a dia. A “ciência doméstica” (DINIZ, 2016a) é apreendida e repassada entre elas, sendo que hoje conseguem trocar sondas, buttons ${ }^{13}$, diminuir e/ou aumentar a dose de medicamentos dos filhos/as, ou prever crises convulsivas. Conhecem tratamentos alopáticos, homeopáticos, terapias e medicamentos com nomes indizíveis, utilizando as redes sociais para adquirirem conhecimento e acesso a seus direitos. Passado o período em que ninguém sabia de nada sobre a epidemia e suas consequências, sobre termos científicos e linguagens abstratas, não é de admirar que tentem se precaver diante de um futuro incerto sobre a vida (ou morte) de seus filhos.

Certamente, no momento em que Martina, Gisele, Katia e outras mulheres se deram conta do que se tratavam todos esses termos empregados pela biomedicina (Zika Vírus, micro, estímulo) perceberam que o esforço para chegar a diagnósticos precisos, lhes garantindo o alcance de tais estímulos às crianças, lhe custaria um conjunto de terríveis experiências de alta vulnerabilidade e de pouca assistência nessa corrida acelerada contra o "tempo".

\section{Considerações Finais}

O Estado se omite ao não estabelecer devidamente um sistema nacional de atendimento aos direitos reprodutivos das mulheres, penalizando-as duplamente: primeiro, pelas consequências de um mau atendimento por meio de políticas públicas falhas; por conseguinte, quando as empurram para instituições que as violentam em seus direitos fundamentais.

Num processo marcado fortemente pela iniquidade de gênero, classe e raça, observa-se que são justamente as mulheres, pobres e negras, que enfrentam o verdadeiro caos de um Estado omisso e dissidente. A maioria delas, residentes em periferias, são as que 
enfrentam graves consequências decorrentes de antigos problemas sociais de direitos fundamentais, abrangendo o acesso à água e ao saneamento, as disparidades raciais, socioeconômicas no acesso à saúde e as restrições dos direitos sexuais e reprodutivos. A ordem deveria fugir aos retrocessos, seja em relação aos direitos reprodutivos das mulheres, seja em relação ao surto do Zika Vírus ou de outras epidemias de forma geral.

A alocação de recursos e de cuidados em saúde são escassos e poderiam ser definidos com maior acuidade, a partir de um olhar não somente da biomedicina e de gestores de saúde, mas que envolvesse o conhecimento e a experiência dessas mulheres que lidam com o drama social da deficiência todos os dias. A vontade política e a atenção precisariam estar focadas nas principais medidas que poderiam resolver os problemas relacionados ao zika e as suas consequências na saúde da população.

A explicação amplamente aceita pelos especialistas brasileiros e estrangeiros sobre o zika ser responsável pelas doenças congênitas em recém-nascidos ainda gera questionamentos. Explicação que, segundo a Opas (2016) e Lowi (2019), levou inclusive a Organização Mundial da Saúde (OMS) a declarar o zika uma Emergência de Saúde Pública de Interesse Internacional (ESPII).

Tal fato, embora aceito por minhas interlocutoras, levantou outras dúvidas por parte dessas mulheres, as quais argumentaram que "o mosquito não agiu sozinho". Elas não duvidam que o zika tenha interferido no desenvolvimento uterino de seus filhos, mas a maioria observa que se a contaminação fosse apenas pelo mosquito, outras regiões do país também teriam sido contaminadas na mesma proporção, a exemplo do norte do Brasil. O argumento principal, em seu campo de possibilidades, diria respeito à articulação de um lote de vacinas para gripe, contaminado com mercúrio, o qual teria potencializado o efeito do Zika Vírus em seus corpos.

Penso que a narrativa por parte de minhas interlocutoras problematiza um discurso oficial, refletindo questões inquietantes para elas, ao mesmo tempo em que dá visibilidade as suas experiências e aos saberes localizados. De qualquer modo, as inquietações dessas 
mulheres não deixam de ter sentido e ainda hoje trazem muitas dúvidas ao mundo científico ${ }^{14}$ : por que, afinal, a Região Nordeste foi a mais atingida? Qual seria exatamente a associação entre o Zika Vírus e as diversas anomalias em recém-nascidos (LOWI, 2019)? Haveria, além da infecção pelo vírus, outros fatores que causariam essas anomalias, conforme questionam minhas interlocutoras? Por que em nosso país pouco se fala na transmissão do Zika Vírus por relação sexual? O Brasil, que já passou duas vezes por essa epidemia (2015/2016), poderia se tornar novamente alvo do surto?

Deve-se levar em consideração que epidemias são eventos complexos e certamente guardam episódios e questões complicadas para todos nós que fazemos parte desse cenário. Não obstante a epidemia tenha arrefecido nos últimos tempos, ela acabou por deixar sequelas irreversíveis que não podem ser esquecidas junto com o fim da emergência nacional decretada pelo $\mathrm{MS}^{15}$. Sequelas que nos afetam como cientistas e afeta nossas preocupações epistemológicas, mas que também nos relega a ação como mulheres, feministas e cidadãs solidárias aos direitos humanos.

\section{Notas}

1 O Zika Vírus, um flavivírus transmitido por um mosquito que está relacionado com o vírus da dengue e é passado principalmente pelo Aedes Aegypti. Foi originalmente isolado de uma fêmea de macaco Rhesus febril na Floresta Zika, localizada próximo de Entebbe na Uganda, em 20/04/1947 (VASCONCELOS, 2015; CUGOLA; FERNANDES; RUSSO, 2016).

2 Segundo Scott et al. (2018), "[...] novas informações e efeitos detectados como oriundos da infecção por Zika tornaram necessária a revisão do conceito de microcefalia e sua substituição por um termo mais abrangente, a Síndrome Congênita de Zika (SCZ), dada a abrangência do espectro de sintomas e lesões que ao longo desse período foram associados ao efeito do vírus".

3 Essa informação pode ser consultada em: http://epoca.globo.com/tempo/ noticia/2015/1 1/o-avanco-do-surto-de-microcefalia.html.

4 Compreendo gênero como um sistema de prestígio, que atravessa, no contexto pesquisado, a agência e as práticas de poder: “[...] um sistema de discursos e práticas que constroem masculinidades e feminilidades não somente em termos de papeis diferenciais e significados, mas também em termos de valor diferencial, prestígio diferencial" (ORTNER, 1996, p. 143).

5 Desde a década de 1970, os estudos sobre o feminismo negro têm se dedicado a compreender as especificidades das mulheres negras como sujeitas de direito, fato que se intersecciona, inevitavelmente, às questões de raça, classe e gênero. Nesse aspecto, ver Davis (2016), Werneck (2016), entre outras. 
6 Gostaria de registrar meus agradecimentos sinceros as/os interlocutoras/es desta pesquisa, assim como às minhas orientandas Thais Valim e Fernanda Moura. Do mesmo modo, agradeço aos pareceristas da Revista Ilha.

7 O prefixo "micro" foi acionado pelas mulheres mães de crianças com microcefalia (assim como pelos profissionais de saúde) de muitas maneiras, tal qual demonstram Alves e Fleischer (2018, p. 7) em sua pesquisa no Recife/PE.

8 O itinerário terapêutico inicia-se com o diagnóstico da enfermidade, seguido pela procura de solução que se realiza em várias etapas. Nessa trajetória participam vários sujeitos - parentes, amigos, conhecidos, vizinhos, especialistas diversos - os quais oferecem diferentes interpretações, possibilidades e/ou soluções de cura para o sofrimento (LANGDON, 1994).

9 Minhas interlocutoras têm conhecimento de outras associações localizadas em Recife: Aliança de Mães e Famílias Raras (AMAR) e a União de Mães de Anjos (UMA). A UMA destaca-se por se dedicar tão somente a crianças com SCZ. Elas gostariam que a MED/RN se espelhasse nessas duas associações no amparo e assistência a essas famílias.

${ }^{10}$ Nesses casos, não somente famílias e crianças são prejudicadas, o CRI é uma instituição criada pelo governo do Estado do Rio Grande do Norte, e os servidores também ficam extremamente prejudicados pelo constante atraso de seus salários.

11 BPC-LOAS: Benefício de Prestação Continuada - Lei Orgânica de Assistência Social - benefício assistencial em que a pessoa com deficiência tem direito ao recebimento de um salário mínimo mensal (Lei Federal n. 8.742, de 7 dezembro de 1993).

12 Reclamação, aliás, bastante proferida pelas mulheres indígenas moradoras de uma comunidade pesquisada na região de Macaíba, sobre a qual estamos investigando.

13 Button é um dispositivo de para alimentação gastroenteral, funciona como uma espécie de sonda introduzida cirurgicamente no estômago (gastrostomia).

14 Não estou afirmando que as desconfianças de minhas interlocutoras sejam verdadeiras ou deixem de ser. A intenção, como cientista, é levantar hipóteses que auxiliem na reflexão.

15 No Brasil, para ser uma emergência global, necessita ser algo não usual, extraordinário e/ou desconhecido.

\section{Referências}

ALVES, R. L. C.; FLEISCHER S. O Que Adianta Conhecer Muita Gente e no Fim das Contas Estar Sempre só? Desafios da maternidade em tempos de Síndrome Congênita do Zika Vírus. Revista Anthropológicas, [S.l.], v. 29, n. 2, p. 6-27, 2018.

AZEREDO, Y.; SCHRAIBER, L. B. Violência institucional e humanização em saúde: apontamentos para o debate Institucional. Ciência \& Saúde Coletiva, [S.l.], v. 22, n. 9, p. 3.013-3.022, 2017.

BOLETIM SESAP. 2019a. Disponível em: http://www.saude.rn.gov.br/ Conteudo.asp. Acesso em: 14 maio 2020. 
BOLETIM SESAP. Diretora da OPAS informa autoridades de saúde globais sobre o vírus Zika nas Américas. [2019b]. Disponível em: http://www.paho.org/bra/index.php?option=com_contentEview=article\& $\mathrm{id}=4985$ :diretora-da-opas-informa-autoridades-de-saude-globais-sobre-ovirus-zika-nas-americas\&Itemid=816. Acesso em: 13 maio 2020.

BRASIL. Secretaria de Atenção à Saúde. Protocolo de atenção à saúde e resposta à ocorrência de microcefalia relacionada à infecção pelo vírus Zika. Brasília: Ministério da Saúde, 2015a. (Plano Nacional de Enfrentamento à Microcefalia).

BRASIL. Secretaria de Vigilância em Saúde. Departamento de Vigilância das Doenças Transmissíveis. Protocolo de vigilância e resposta à ocorrência de microcefalia relacionada à infecção pelo vírus Zika - MS. Secretaria de Vigilância em Saúde, Departamento de Vigilância das Doenças Transmissíveis, Brasília, DF: Ministério da Saúde, 2015 b.

CAMPOS, T. C. de. Zika, public health, and the distraction of abortion. Med Health Care and Philos, [S.l.], v. 20, p. 443-446, 2017.

CARNEIRO, R.; FLEISCHER, S. Eu não esperava por isso, foi um susto: conceber, gestar e parir em tempos de zika à luz das mulheres de Recife/PE, Brasil. Interface, Botucatu, v. 22, p. 709-719, 2018.

CARVALHO, L. P. Vírus zika e direitos reprodutivos: entre as políticas transnacionais, as nacionais e as ações locais. Cadernos de Gênero e Diversidade, Bahia, v. 3, n. 2, maio-agosto, 2017.

COSTA, M.; PORTO, R. Negociações do corpo: reflexões sobre o acesso ao aborto legal em uma maternidade potiguar. In: MALUF, Sônia Weidner; SILVA, Érica Quinaglia (org.). Estado, políticas e agenciamentos sociais em saúde: etnografias comparadas/Florianópolis: EdUFSC, 2018. p. $121-144$.

COSTA, P.; PORTO, R. Zika vírus e microcefalia: o debate políticoinstitucional que movimentou o Brasil. In: DIAS, Alfrancio Ferreira; SANTOS, Elza Ferreira; CRUZ, Maria Helena Santana (org.). Gênero e sexualidades: entre invenções e desarticulações. Sergipe: IFS, 2017. v. 1. p. 247-266.

CUGOLA, F. R.; FERNANDES, I. R.; RUSSO, F. B. The Brazilian zika virus strain causes birth defects in experimental models. Nature, [S.l.], 2016. DOI:10.1038/nature18296. Published online 11 May 2016.

DAVIS, Â. Mulheres, raça e classe. São Paulo: Boitempo, 2016.

DINIZ, D. Zika: do sertão nordestino à ameaça global. 1. ed. Rio de Janeiro: Civilização Brasileira, 2016a. 
DINIZ, D. Vírus zika e mulheres. Cadernos de Saúde Pública, [S.l.], v. 32, p. 1, 2016b.

FAVRET-SAADA, J. Être affecté. Gradhiva: Revue d'Histoire et d'Archives de l'Anthropologie, [S.l.], 8. p. 3-9, 1990.

FLEISCHER, S. Segurar, caminhar e falar: notas etnográficas sobre a experiência de uma "mãe de micro" no Recife/PE. Cadernos de Gênero e Diversidade, Bahia, v. 3, n. 2, maio-agosto, 2017.

FONSECA, C. De afinidades a coalizões: uma reflexão sobre a "transpolinização" entre gênero e parentesco em décadas recentes da antropologia. Ilha, Revista de Antropologia, v. 5, n. 2, 2003.

FUNCK, S. B. Desafios atuais dos feminismos. In: STEVENS, Cristina; OLIVEIRA, Susane Rodrigues de; ZANELLO, Valeska (org.). Estudos feministas e de gênero: articulações e perspectivas. Florianópolis: Mulheres, 2014. (versão eletrônica). p. 22-35.

GARNELO, L.; LANGDON, J. A antropologia e a reformulação das práticas sanitárias na atenção à saúde básica. In: MINAYO, M. C. S.; COIMBRA JR. C. E. A. (org.). Críticas e Atuantes: Ciências Sociais e Humanas em Saúde na América Latina. Rio de Janeiro: Fiocruz; 2005. 708 p.

GASTÓN, V. P. Depresión y/o ansiedad en gestantes que viven en zona de primeraintroducción con transmisión activa del virus del zika, que acuden a control prenatal en el hospital regional de Loreto, Setiembre 2017. Tesis para optar El Titulo De Médico Cirujano Universidad Nacional De La Amazonia Peruana Facultad De Medicina Humana "Rafael Donayre Rojas". Medicina Humana: Asesor: Dr. Javier Vásquez Vásquez -Iquitos-Peru, 2018.

LANGDON, E. J. Representações de doenças e itinerário terapêutico dos Siona da Amazônia colombiana. In: SANTOS, R. V.; COIMBRA JR., C. E. A. (org. ). Saúde e Povos Indígenas. Rio de Janeiro: Fiocruz, 1994.

LIRA, L. C. de; SCOTT, R. P.; MEIRA, F. Trocas, gênero, assimetrias e alinhamentos: experiência etnográfica com mães e crianças com síndrome congênita do Zika. Revista Anthropológicas, [S.l.], v. 28, n. 2, p. 206-237, 2017.

LÓPEZ, L. C. O conceito de racismo institucional: aplicações no campo da saúde. Interface, Comunicação Saúde Educação, [S.l.], v. 16, n. 40, p. 121-34, jan.-mar. 2012.

LOWY, I. Zika no Brasil: história recente de uma epidemia. Rio de Janeiro: Fiocruz, 2019.

MACHADO, L. Z. Dádivas, conflitualidades e hierarquias na saúde. In: MARTINS, Paulo Henrique; CAMPO, Roberta (org.). Polifonia do dom. Recife: Editora Universitária da UFPE, 2006. p. 32-45. 
MALUF, S. W. Biolegitimidade, direitos e políticas sociais: novos regimes biopolíticos no campo da saúde mental no Brasil. In: MALUF, Sônia Weidner; SILVA, Érica Quinaglia (org.). Estado, políticas e agenciamentos sociais em saúde: etnografias comparadas/Florianópolis: EdUFSC, 2018. p. 15-44.

NASCIMENTO, P.; MELO, A. C. de. Esse povo não está nem aí: as mulheres, os pobres e os sentidos da reprodução em serviços de atenção básica à saúde em Maceió, Alagoas. In: FERREIRA, Jaqueline; FLEISCHER, Soraya. Etnografias em serviços de saúde. 1. ed. Rio de Janeiro: Garamond, 2014. p. 267-298.

OPAS - ORGANIZAÇÃO PAN-AMERICANA DE SAÚDE. Diretora da OPAS informa autoridades de saúde globais sobre o vírus Zika nas Américas. 2016. Disponível em: http://www.paho.org/bra/ index.php?option $=$ com_content\&view $=$ article\&id $=4985$ :diretora-daopas-informa-autoridades-de-saude-globais-sobre-o-virus-zika-nasamericas\&Itemid=816. Acesso em: $1^{\circ}$ fev. 2016 .

ORTNER, S. B. Making gender: the politics and erotics of culture. Boston: Beacon Press, 1996.

PINHEIRO, D. A.; REIS, M. Maternidade como missão! a trajetória militante de uma mãe de bebê com microcefalia em Pernambuco.

Cadernos de Gênero e Diversidade, Bahia, v. 3, n. 2, maio-agosto, 2017.

PORTO, R.; COSTA, P. O corpo marcado: a construção do discurso midiático sobre zika virus e microcefalia. Dossiê Zika, Síndromes Neurólogicas Congênitas e Gênero. Cadernos Gênero e Diversidade, Bahia, 2017.

PORTO, R.; SOUSA, C. H. D. Percorrendo Caminhos da Angústia: Cytotec e os itinerários Abortivos em uma Capital do Nordeste Brasileiro. Revista Estudos Feministas, Florianópolis, v. 25, p. 1-20, 2017.

POSENATO GARCIA, L. Epidemia do vírus zika e microcefalia no

Brasil: emergência, evolução e enfrentamento. Brasília, DF; Rio de Janeiro: Instituto de Pesquisa Econômica Aplicada, 2018. (Texto para discussão)

RASANATHAN, J. J. K. et al. La importancia de los derechos humanos en la respuesta ante el avance de la epidemia de la infección por el virus del Zika. Public Health, [S.l.], v. 107, p. 525-531, 2017 a.

ROHDEN, F. Uma ciência da diferença. Rio de Janeiro: Fiocruz, 2001.

SCAVONE, L. A maternidade e o feminismo: diálogo com as ciências sociais. Cadernos Pagu, [S.l.], v. 16, p.137-150, 2001.

SCOTT, R. P.; QUADROS, M. T.; RODRIGUES, A. C. A epidemia de zika e as articulações das mães num campo tensionado entre feminismo, deficiência e cuidados. Cadernos de Gênero e Diversidade, Bahia, v. 3, n. 2, maioagosto, 2017. 
SCOTT, R. P.; LIRA, L.; MATOS, S. Itinerários terapêuticos, cuidados e atendimento na construção de ideias sobre maternidade e infância no contexto da Zika. Interface: Comunicação, Saúde e Educação, [S.l.], Dossiê: Zika vírus: uma epidemia em/e seu mundo social, 2018.

SEGATA, J. A doença socialista e o mosquito dos pobres. Iluminuras, Porto Alegre, v. 17, n. 42, p. 372-389, ago.-dez. 2016.

SOARES, A. The Zika Epidemic in Brazil: State and the (re)Production of Inequalities. GT: Políticas Públicas de Saúde, Direitos Reprodutivos e Desigualdades. In: II RAS - REUNIÃO DE ANTROPOLOGIA DA SAÚDE, UnB, Brasília, 2017. Anais [...]. Brasília, DF, 2017.

\section{VALIM, T. Um olhar antropológico sobre a sociabilidade de bebês nascidos com a Síndrome Congênita do Zika Vírus em Recife/} PE: "ele sente tudo o que a gente sente". 2017. 78 f. Conclusão de Curso (Bacharelado em Ciências Sociais ) - Universidade de Brasília, Brasília, DF, 2017.

VASCONCELOS, P. F. da C. Doença pelo vírus zika: um novo problema emergente nas Américas? Revista Pan-Amaz Saúde, Ananindeua, v. 6, n. 2, p. 9-10, junho 2015 .

WERNECK, J. Racismo institucional e saúde da população negra. Revista Saúde e Sociedade, [S.l.], 2016.

WILLIAMSON, K. E. Cuidado nos tempos de zika: notas da pós-epidemia em Salvador (Bahia), Brasil. Interface, Botucatu, v. 22, p. 686-696, 2018.

Recebido em 31/08/2019

Aceito em 15/05/2020

\section{Rozeli Maria Porto}

Professora Associada II do Departamento de Antropologia (DAN) e do Programa de Pós-Graduação em Antropologia Social (PPGAS) da Universidade Federal do Rio Grande do Norte/UFRN. Faz parte de la Red Del Laboratorio Iberoamericano para el Estudio Sociohistorico de las Sexualidades/Espanha [RED LIESS], do Grupo Gênero, Corpo e Sexualidades (GCS/UFRN), do Núcleo de Identidades de Gênero e Subjetividades (NIGS/UFSC), do Laboratório das Violências (LEVIS) e da Rede de Antropologia e Saúde (RAS). Sócia efetiva e membro do Comitê Científico e do Comitê Gênero e Sexualidades da Associação Brasileira de Antropologia (ABA). Tem experiência na área de Teoria Antropológica, Antropologia do Corpo, da Saúde e da Doença, Antropologia das Relações de Gênero (com enfoques e articulações em Saúde Reprodutiva, Itinerários Terapêuticos, Doenças pan/epidêmicas, Medicamentos, Feminismos e Violências).

Endereço Profissional: Universidade Federal do Rio Grande do Norte/UFRN. Campus Universitário - Avenida Senador Salgado Filho, SN - Lagoa Nova,Natal, RN. CEP: 59078-970.

E-mail:rozeliporto@gmail.com 